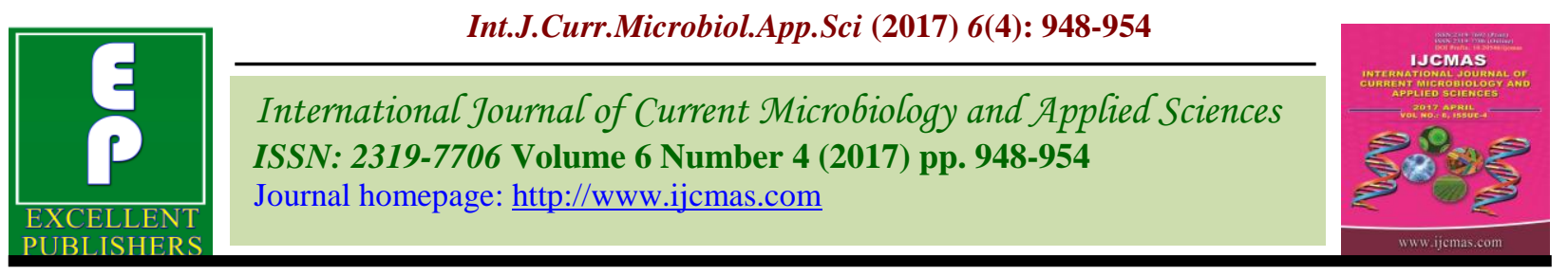

Original Research Article

https://doi.org/10.20546/ijcmas.2017.604.119

\title{
Genetic Divergence of Newly Developed Thirty Eight Maintainer Lines of Rice (Oryza sativa L.) for Yield and Grain Quality Characters
}

\author{
Ashok Kumar Meena*, J. Suresh ${ }^{1}$, Vijay Pancholee ${ }^{1}$, M. Mahanthesha ${ }^{1}$ and H.P. Meena ${ }^{2}$ \\ ${ }^{1}$ Acharya N.G. Ranga Agricultural University, Rajendranagar, Hyderabad-500030, India \\ ${ }^{2}$ Scientist (Plant Breeding), ICAR-Indian Institute of Oilseeds Research, Rajendranagar, \\ Hyderabad-500030, India \\ *Corresponding author
}

\section{A B S T R A C T}

Keywords

Rice,

Genetic divercity,

Mohalanobis's D2,

Cluster.

Article Info

Accepted:

06 March 2017

Available Online:

10 April 2017
Genetic divergence of thirty eight maintainer lines was studied through Mohalanobis's D ${ }^{2}$ and principal component analysis for eleven characters in a randomized complete block design (RCBD) in Kharif 2014 at Rice section farm, Agriculture Research Institute, Rajendranagar, Hyderabad. Genotypes were grouped into five different clusters. Cluster IV comprised maximum number of genotypes (thirteen) followed by cluster V and III. The inter-cluster distance was maximum between clusters I and V (35.700) indicating wide genetic diversity between these two clusters followed by the distance between cluster I and IV (30.090), cluster I and cluster III (26.530) and cluster II and cluster V (22.800). The minimum inter-cluster distance was observed between cluster III and cluster IV (3.600) followed by cluster IV and cluster V (5.920) and cluster V and cluster III (9.450) indicating that the genotypes of these clusters were genetically close. The intra cluster distance in the entire five clusters was more or less low indicated the genotypes within the same cluster were closely related. Among the characters number of panicles $/ \mathrm{m}^{2}$, number of grains per panicle, number of effective tillers and grain yield per plot contributed most for divergence in the studied genotypes. Therefore, these characters may be given importance during hybridization programme.

\section{Introduction}

Rice is the fundamental principal food for about half of the world's population, supplying $20 \%$ of the calories consumed worldwide. Rice consumption increases with the population. In the $21^{\text {st }}$ century, a large population increase is predicted. Most of the increase will occur in Asia and Africa, where the population lives on rice. There are many indications that the food problem will become as important as the environmental problem. With mankind's food crisis becoming an issue in the future (Schwartz, 1991), this research seeks to clarify the future relationship of supply and demand of rice, which is intimately connected with Asia. Presently Asia grows 520 million tonnes of paddy on 135 million hectares; this is 92 per cent of the world's total of 568 million tonnes on 149 million hectares. By 2020, rice production must increase to 690 million tonnes to feed the rapidly increasing population. Thus, there is need to produce more rice per unit area per unit time. Achieving self sufficiency in rice production and maintaining price stability are 
important political objectives in countries where rice provides food security and generates employment and income for people (Hossain, 1995). Yuan (2001) reported that more than $50 \%$ of rice area in China is covered by hybrid rice. Expansion of hybrid rice cultivation area may be an effective and economic way to meet the future rice demands of growing population. Hybrid rice technology offers considerable opportunity for India to increase the productivity of rice. Use of rice hybrids is getting popular in India day by day. The performance and heterosis of hybrids are associated with genetic divergence between their parental lines. The selection of parental lines plays a vital role in developing ideal combinations. Study of diverse genotypes of a crop is necessary to evaluate their performances which help to develop a new variety suitable for commercial cultivation and maximizes the exploitation of the genetic resources. Grouping or classification of genotypes based on suitable scale is quite imperative to understand the usable variability existing among them. Selection of suitable parental lines to develop heterotic combinations can be facilitated by determining genetic divergence among them. Careful selection of lines on the basis of their genetic diversity may lead to the development of hybrids with higher yield potential than parents and standard check varieties (Julfiquar et al., 1985). Thus keeping in view the above facts, present study was conducted to estimate the nature and magnitude of genetic divergence and characters contributing to the genetic divergence of thirty eight rice genotypes. This study was undertaken to determine the genetic diversity in rice for the maximum utilization of the genetic resources and proper selection of donor parents.

\section{Materials and Methods}

Thirty eight rice genotypes were obtained from Plant Breeding Section, Crop
Improvement Division, ICAR-Indian Institute of Rice Research (formerly, Directorate of Rice Research), Rajendranagar, Hyderabad. The present experiment was carried out at Rice section farm, Agriculture Research Institute, Rajendranagar, Hyderabad. The details of genotypes are furnished in table 1 . The experiment was laid out in a randomized block design (RBD) with two replications. All the genotypes were sown on $2^{\text {nd }}$ July, 2013 separately in the nursery on raised beds. Thirty days old seedlings were transplanted $20 \mathrm{~cm}$ apart between rows and $15 \mathrm{~cm}$ within the row. All necessary precautions were taken to maintain uniform plant population in each treatment per replication. All the recommended package of practices was followed along with necessary prophylactic plant protection measures to raise a good crop. Five representative plants for each genotype in each replication were randomly selected to record observations on the quantitative characters like days to 50 per cent flowering, plant height $(\mathrm{cm})$, productive tillers per plant, panicle length $(\mathrm{cm})$, number of filled grains per panicle, 1000-grain weight (g), grain yield per plant (g), hulling percentage $(\%)$, milling percentage $(\%)$, head rice recovery percentage (\%), kernel length $(\mathrm{mm})$, kernel breadth $(\mathrm{mm})$ and $\mathrm{L} / \mathrm{B}$ ratio under study. The L/B ratio was calculated by using the following formula of Murthy and Govindaswamy (1967).Statistical analyses for the above characters were done following Singh and Chaudhary (1995) for correlation coefficient and Wright (1921) and Dewey and $\mathrm{Lu}$ (1959) for path analysis. Genetic diversity between genotypes can be better estimated using $\mathrm{D}^{2}$ statistics given by Mahalanobis (1936). Grouping of genotypes into different clusters was done by using Tocher's method.

\section{Results and Discussion}

The use of Mahalanobis D2 statistics for estimating genetic divergence has been 
emphasized by many workers (Roy and Ponwar, 1993; Ramya and Senthil Kumar, 2008). The computations from distance matrix gave nonhierarchical clustering among 38rice genotypes and grouped them into ten clusters (Table 1).Divergence studies through $\mathrm{D}^{2}$ statistic indicated the presence of substantial diversity by forming large number of clusters with wide range of inter-cluster distances. The diversity was more for 1000-grain weight, kernel breadth, grain yield per plant, plant height, kernel L/B indicating their importance in contribution towards genetic diversity. The genetic divergence was high and the 38 genotypes of rice were grouped into 10 divergent clusters. I was the largest comprising of twenty nine genotypes and all other clusters II,III IV, V, VI,VII, VIII, IX and $\mathrm{X}$ were represented by single genotype indicating high degree of heterogeneity among the genotypes. The pattern of group constellations indicated significant variability among the genotypes. The higher amount of divergence was observed between cluster from the inter cluster $\mathrm{D}^{2}$ values of the ten clusters, it can be seen that the highest divergence occurred between cluster $\mathrm{V}$ and $\mathrm{X}$ (23.65) followed by cluster V and VIII (22.07) cluster VI and X (20.49), cluster), cluster IV and VIII (20.08) and cluster VI and VIII (19.78), cluster III and VIII (19.67) suggesting that the crosses involving varieties from these clusters would give wider and desirable recombination. Maximum intra cluster distance was observed in cluster I (8.78) is suggested to generate promising segregants for grain yield and quality traits would produce encouraging results. Crosses involving parents belonging to the most divergent clusters would be expected to manifest maximum heterosis and wide variability of genetic architecture (Souroush et al., 2004).

The cluster VIII is having highest mean value for number of filled grains per panicle and thousand grain weight, cluster VII for grain yield per plant and cluster $\mathrm{X}$ is having highest number of productive tillers per plant, head rice recovery, kernel breath and cluster VI for hulling percentage, high milling percentage and cluster III having highest plant height, panicle length, II having highest kernel length and cluster IV having high L/B ratio, cluster. The genotypes RNR-19371, RNR-19420, MTU-1010, MTU- 1001 and RNR-1936from these clusters having high mean values may be directly used for adaptation or may be used as parents in future hybridization programme. The results showed that the contribution of 1000 grain weight was highest towards genetic divergence (24.75) followed by kernel length $(23.61 \%)$, grain yield per plant (17.35\%), plant height $(11.10 \%)$, L/B Ratio $(8.53 \%)$, kernel length $(4.84 \%)$, Number of filled grains per panicle $(3.84 \%)$, number of productive tillers per plant $(1.85 \%)$, panicle length $(1.56 \%)$, milling percentage $(0.85$, days to $50 \%$ flowering $(0.71 \%)$, head rice recovery $(0.57 \%)$ and hulling percentage $(0.43 \%)$ is respectively to the genetic divergence in decreasing order.

Similar result were conformity with Senapati et al., (2005) and Reddy et al., (2002); Latif et al., 2011 and Sabesan et al., 2009 for 1000grain weight, Chandra et al., (2007) for 1000grain weight, grain length, number of grains per panicle and plant height, and Surender Raju (2002) for kernel length, Vennila et al., (2011) number of grains per panicle, plant height, kernel length and L/B Ratio, Raut et al., (2009)for length to breadth ratio of grain, number of grains per panicle contributed maximum towards genetic diversity. Genotypes of distantly located clusters were suggested to use in hybridization programs for obtaining a wide spectrum of variation among the segregates as suggested by Yadav et al., (2011), Vennila et al., (2011) and Latif et al., (2011). 
Table.1 Pedigree details of 38 rice genotypes used in the study

\begin{tabular}{|c|c|c|}
\hline S. No. & Genotype & Pedigree \\
\hline 1 & RNR- 19358 & MTU $-1075 \times$ WGL-32100 \\
\hline 2 & RNR- 19359 & MTU -1075 × WGL-32100 \\
\hline 3 & RNR- 19360 & MTU $-1075 \times$ WGL-32100 \\
\hline 4 & RNR- 19361 & MTU $-1075 \times$ WGL-32100 \\
\hline 5 & RNR- 19362 & MTU $-1075 \times$ WGL-32100 \\
\hline 6 & RNR- 19363 & MTU $-1075 \times$ WGL-32100 \\
\hline 7 & RNR- 19366 & MTU $-1075 \times$ WGL-32100 \\
\hline 8 & RNR- 19367 & MTU -1075 × WGL-32100 \\
\hline 9 & RNR- 19368 & MTU $-1075 \times$ WGL-32100 \\
\hline 10 & RNR- 19369 & MTU $-1075 \times$ WGL-32100 \\
\hline 11 & RNR- 19370 & MTU $-1075 \times$ WGL-32100 \\
\hline 12 & RNR- 19371 & MTU $-1075 \times$ WGL-32100 \\
\hline 13 & RNR- 19372 & MTU $-1075 \times$ WGL-32100 \\
\hline 14 & RNR- 19374 & BM-71 × WGL-32100 \\
\hline 15 & RNR- 19379 & BM-71 × WGL-32100 \\
\hline 16 & RNR- 19380 & MTU $-1075 \times$ JLG -1798 \\
\hline 17 & RNR- 19381 & MTU $-1075 \times$ JLG -1798 \\
\hline 18 & RNR- 19382 & MTU $-1075 \times$ JL G - 1798 \\
\hline 19 & RNR- 19383 & MTU $-1075 \times$ JLG -1798 \\
\hline 20 & RNR- 19393 & BPT- $4358 \times$ RNR- M7 \\
\hline 21 & RNR- 19396 & IR- $64 \times$ Erramallelu \\
\hline 22 & RNR- 19397 & IR- $64 \times$ Erramallelu \\
\hline 23 & RNR- 19398 & IR- $64 \times$ Erramallelu \\
\hline 24 & RNR- 19399 & IR- $64 \times$ Erramallelu \\
\hline 25 & RNR- 19400 & MTU - $1001 \times$ JLG- 3844 \\
\hline 26 & RNR- 19401 & MTU - $1001 \times$ JLG- 3844 \\
\hline 27 & RNR- 19402 & MTU - $1001 \times$ JLG- 3844 \\
\hline 28 & RNR- 19403 & MTU - $1001 \times$ JLG- 3844 \\
\hline 29 & RNR- 19404 & MTU - $1001 \times$ JLG- 3844 \\
\hline 30 & RNR- 19405 & MTU - $1001 \times$ JLG- 3844 \\
\hline 31 & RNR- 19406 & MTU - $1001 \times$ JLG- 3844 \\
\hline 32 & RNR- 19407 & MTU - $1001 \times$ JLG- 3844 \\
\hline 33 & RNR- 19408 & MTU - $1001 \times$ JLG- 3844 \\
\hline 34 & RNR- 19420 & MTU - $1010 \times$ JLG- 3844 \\
\hline 35 & RNR- 19470 & RNR- $15368 \times$ Erramallelu \\
\hline 36 & MTU - 1001 & JLG - $418 \times$ Gedongibetom \\
\hline 37 & MTU- 1010 & Krishnaveni $\times$ IR-64 \\
\hline 38 & BPT-1 010 & Vajram $\times$ MTU- 7014 \\
\hline
\end{tabular}


Table.2 Average Intra (diagonal) and inter-cluster D2 values for thirteen characters in thirty eight genotypes of rice (Oryza sativa L.)

\begin{tabular}{|c|c|c|c|c|c|c|c|c|c|c|}
\hline & Cluster I & Cluster II & Cluster III & Cluster IV & Cluster V & Cluster VI & Cluster VII & Cluster VIII & Cluster IX & Cluster X \\
\hline Cluster I & 8.78 & 11.22 & 10.65 & 10.83 & 12.41 & 11.30 & 13.21 & 14.05 & 12.90 & 16.50 \\
\hline Cluster II & & 0.00 & 15.72 & 13.14 & 15.21 & 14.00 & 8.22 & 13.51 & 9.44 & 14.00 \\
\hline Cluster III & & & 0.00 & 7.58 & 6.70 & 8.88 & 17.95 & 19.67 & 17.38 & 21.99 \\
\hline Cluster IV & & & & 0.00 & 7.31 & 6.84 & 14.92 & 20.08 & 14.65 & 19.74 \\
\hline Cluster V & & & & & 0.00 & 7.23 & 18.43 & 22.07 & 17.55 & 23.65 \\
\hline Cluster VI & & & & & & 0.00 & 16.90 & 19.78 & 16.64 & 20.49 \\
\hline Cluster VII & & & & & & & 0.00 & 14.97 & 9.47 & 14.27 \\
\hline Cluster VIII & & & & & & & & 0.00 & 15.93 & 10.52 \\
\hline Cluster IX & & & & & & & & & 0.00 & 15.09 \\
\hline Cluster X & & & & & & & & & & 0.00 \\
\hline
\end{tabular}

Table.2 Cluster means for yield components and quality traits (D2 analysis) for thirteen characters in thirty eight genotypes of rice (Oryza sativa L.)

\begin{tabular}{|c|c|c|c|c|c|c|c|c|c|c|c|c|c|}
\hline Cluster No. & $\begin{array}{l}\text { Days to } \\
50 \% \\
\text { flowering }\end{array}$ & $\begin{array}{l}\text { Plant } \\
\text { height } \\
(\mathrm{cm})\end{array}$ & $\begin{array}{l}\text { Panicle } \\
\text { Length } \\
(\mathrm{cm})\end{array}$ & $\begin{array}{l}\text { Number of } \\
\text { productive } \\
\text { tillers / plant }\end{array}$ & \begin{tabular}{|l|}
$\begin{array}{l}\text { Number } \\
\text { of filled } \\
\text { grains / } \\
\text { Panicle }\end{array}$ \\
\end{tabular} & $\begin{array}{l}\text { Grain } \\
\text { yield } \\
\text { plant }(g)\end{array}$ & $\begin{array}{l}\text { 1000- } \\
\text { Grain } \\
\text { Weight } \\
\text { (g) }\end{array}$ & $\begin{array}{l}\text { Hulling } \\
\%\end{array}$ & $\begin{array}{l}\text { Milling } \\
\%\end{array}$ & $\begin{array}{l}\text { Head Rice } \\
\text { Recovery }\end{array}$ & $\begin{array}{l}\text { Kernel } \\
\text { Length } \\
(\mathbf{m m})\end{array}$ & $\begin{array}{l}\text { Kernel } \\
\text { Breadth } \\
(\mathrm{mm})\end{array}$ & L/B Ratio \\
\hline II & 102.00 & 116.15 & 24.60 & 6.00 & 123.50 & 8.94 & 22.82 & 82.36 & 71.29 & 35.88 & 6.02 & 1.95 & 3.10 \\
\hline III & 101.50 & 154.45 & 27.65 & 5.00 & 109.00 & 8.45 & 13.00 & 76.38 & 65.08 & 61.26 & 4.73 & 1.44 & 3.29 \\
\hline IV & 108.50 & 143.80 & 27.25 & 5.50 & 135.50 & 8.92 & 15.09 & 76.06 & 60.86 & 55.23 & 5.11 & 1.38 & 3.72 \\
\hline $\mathrm{V}$ & 102.00 & 144.50 & 28.00 & 6.00 & 108.00 & 6.31 & 14.72 & 84.39 & 62.70 & 55.27 & 4.77 & 1.47 & 3.26 \\
\hline VI & 95.00 & 132.45 & 26.35 & 6.50 & 138.50 & 8.29 & 15.24 & 88.12 & 73.84 & 58.25 & 4.98 & 1.35 & 3.69 \\
\hline V II & 103.50 & 102.70 & 25.85 & 5.50 & \begin{tabular}{|l|}
194.00 \\
\end{tabular} & 11.80 & 23.69 & 78.71 & 68.68 & 51.85 & 5.66 & 1.83 & 3.12 \\
\hline VIII & 99.50 & 99.90 & 23.75 & 8.50 & 125.50 & 15.54 & 24.71 & 81.39 & 67.72 & 54.67 & 5.99 & 1.94 & 3.09 \\
\hline IX & 110.00 & 79.95 & 18.20 & 6.50 & 148.50 & 10.39 & 15.55 & 76.88 & 56.10 & 46.08 & 5.65 & 1.91 & 2.97 \\
\hline $\mathrm{X}$ & 108.00 & 104.05 & 22.85 & 10.00 & 126.00 & 14.72 & 23.71 & 77.41 & 73.20 & 64.63 & 5.66 & 2.19 & 2.59 \\
\hline
\end{tabular}


The five characters like 1000-grain weight, kernel length, grain yield per plant, plant height and L/B ratio contributed $85.34 \%$ towards total divergence. The result indicates that selection of genotypes having high values for particular trait could be made and used in the hybridization programme for improvement of that character. It is observed that no cluster contained at least one genotype with all the desirable traits, which ruled out the possibility of selecting directly one genotype for immediate use. Hence, these characters should be given importance during hybridization and selection in the segregating population.

The conclusion drawn by the cluster analysis is that in the studied population, high variability observed between the genotypes in different clusters for different traits. Recombination breeding among genotypes belonging to cluster I having maximum intracluster distance can improve the yield potential. As maximum inter-cluster distance was noticed between cluster $\mathrm{V}$ and $\mathrm{X}$, cluster $\mathrm{V}$ and VIII, cluster VI and $\mathrm{X}$, crosses involving genotypes from these clusters would give wider and 'desirable recombination's.

\section{References}

Chandra, B.S., Reddy, T.D and Ansari. 2007. Genetic divergence in rice. Res. Crops, 8(3): 600-603.

Dewey, J.R and Lu, K.H. 1959. Correlation and path coefficient analysis of components of crested wheat grass seed production. Agronomy J., 51: 515-518.

Hossain, M. 1995. Sustaining food security for fragile environments in Asia: achievements, challenges and implications for rice research. In: Fragile lives in fragile ecosystems. Proceedings International Rice Research Conference, 13-17 Feb, 1995, Manila, Philippines. Manila
(Philippines): International Rice Research Institute. p 3-23.

Julfiquar, A.W., Virmani, S.S. and Carpena, A.L. 1985. Genetic divergence among some maintainer and restorer lines in relation to hybrid breeding in rice (Oryza sativa L.). Theor. Appl. Genet., 70(6): 671-678.

Latif, M.A., Rahman, M.M., Kabir, M.S., Ali, M.A., Islam, M.T. and Rafii, M.Y. 2011. Genetic diversity analyzed by quantitative traits among rice (Oryza sativa L.) genotypes resistant to blast disease. African J. Micro. Res., 5(25): 4483-4391.

Mahalanobis, P.C. 1936. On the generalized distance in statistics. Proceed lags of National Institute of Sciences, India. 12: 49-55.

Murthy, P.S.N and Govindaswamy, S. 1967. Inheritance of grain size and its correlation with the hulling and cooking qualities. Oryza, 4(1): 12-21.

Ramya, K. and Senthilkumar, K. 2008. Genetic divergence in rice. Crop Improvement, 35(2): 119-121.

Raut, K.R., Harer, P.N and Yadav, P.S. 2009. Genetic divergence in rice. Maharashtra Agri. Univ., 34(2): 172174.

Roy, A. and Ponwar, D.V.S. 1993. Genetic divergence in rice. Oryza, 30: 197-201.

Sabesan, T., Saravanak, K. and Anandan, A. 2009. Genetic divergence analysis for certain yield and quality traits in rice (Oryza sativa L.) grown in irrigated saline low land of Annamalinagar, South India. J. Central European Agric., 10: 405-410.

Schwartz, S.J. 1991. "World Rise Trade: Prospects and Issue for the Nineties." Rice Situation and Outlook Report. USDA Economic Research Service.

Singh, S and Chaudhary, B.S. 1996. Variability, heritability and genetic advance in cultivars of rice (Oryza 
sativa L. Crop Res., 12(2): 165-167.

Souroush, H.R., Mesbah, M., Hossainzadeh, A. and Bozorgipour, R. 2004. Genetic and phenotypic variability and cluster analysis for quantitative and qualitative traits of rice. Seed and Plant Karaj, 20: 167-182.

Surender Raju, C.H. 2002. Study of genetic divergence, variability, stability, gene action and character association for certain physiological quality and yield components in Rice (Oryza sativa L.) Ph.D. Thesis, Acharya N.G. Ranga Agricultural University, Hyderabad.

Vennila, S., Anbuselvam, Y and Palaniraja, K. 2011. D ${ }^{2}$ analysis of rice germplasm for some quantitative and quality traits. Electronic J. Plant Breeding, 2(3): 392-
403.

Vennila, S., Anbuselvam, Y. and Palaniraja, K. 2011. Genetic divergence analysis using yield and quality traits in rice (Oryza sativa L.). Int. J. Recent Scientific Res., 2(7): 237-239.

Wright, S. 1921. Con-elation and causation. $J$. Agri. Res., 20: 557-585.

Yadav, V.K., Singh, Y., Soni, S.K. and Yadav, A.K. 2011. Genetic divergence analysis in salt tolerance rice (Oryza sativa L.) genotypes. Pl. Arch., 11(2): 593-595.

Yuan, L.P. 2001. Hybrid rice in China: Present status and future vision. Paper presented at BARC in the workshop on Development and Use of Hybrid Rice in Asia.

\section{How to cite this article:}

Ashok Kumar Meena, J. Suresh, Vijay Pancholee, M. Mahanthesha and H.P. Meena. 2017. Genetic Divergence of Newly Developed Thirty Eight Maintainer Lines of Rice (Oryza sativa L.) for Yield and Grain Quality Characters. Int.J.Curr.Microbiol.App.Sci. 6(4): 948-954. doi: https://doi.org/10.20546/ijcmas.2017.604.119 